\title{
Tissue Marking Ink
}

National Cancer Institute

\section{Source}

National Cancer Institute. Tissue Marking Ink. NCI Thesaurus. Code C83194.

A colored ink which is used in surgical pathology to mark tissue margins for proper specimen orientation. 